\title{
IN-VITRO ALPHA-AMYLASE AND ALPHA-GLUCOSIDASE INHIBITION ACTIVITY OF DECALEPIS HAMILTONII WIGHT AND ARN
}

\section{Pharmacology}

Srinivasan, $\mathbf{S *}$

Rayar, A
Department Of Chemistry-DDE, Annamalai University, Annamalai nagar, Tamilnadu, India. ${ }^{*}$ Corresponding Author

Department of Chemistry,Rajah Serfoji Govt. College (Auto) Thanjavur, Tamilnadu, India.

\section{ABSTRACT}

Biologically active polyphenol, D-catechin was isolated from Decalepis hamiltonii and characterized by IR, ${ }^{1} \mathrm{H}-\mathrm{NMR}{ }^{13} \mathrm{C}-\mathrm{NMR}$ and evaluation of its in-vitro $\alpha$-amylase and $\alpha$-glucosidase inhibition activities. Bioactive compounds are deposited in many parts of the plants, such as in roots, stems, leaves, flowers, fruits and seeds. They protect the plants from diseases and contribute aroma, color and flavor. Inhibitors $\alpha-$ amylase and $\alpha$ glucosidase delay the breaking down of carbohydrates in the small intestine and lower the postprandial blood glucose excursion. Methanolic extract showed the greater \% inhibition of the alpha glucosidase enzyme compared to D-catechin. The herbal extracts produced a slightly weak alpha glucosidase enzyme inhibition when compared with alpha amylase.

\section{KEYWORDS}

Decalepis hamiltonii, Methanolic extract, Alpha- amylase, Alpha- glucosidase, $\mathrm{IC}_{50}$, Acarbose

\section{INTRODUCTION}

India has ancient history of traditional medicines, with two widely flourishing systems of treatments i.e. Ayurvedic and Unani systems. The ethno-medicinal wealth has been reported that the plant derived medicines are relatively safer than synthetic drugs and offering profound therapeutic benefits by providing alternative and effective treatment for chronic disorders and various diseases [1].

Herbal medicines have been used for centuries as remedies for human diseases because they contain components of therapeutic value. Many of the currently available drugs were derived directly or indirectly from phytochemicals, Bioactive compounds are deposited in different parts of the plants, such as in roots, stems, leaves, flowers, fruits and seeds. They protect the plants from diseases and contribute color, aroma and flavor. [2]. The quantity and quality of the bioactive compounds vary depending on the variety, processing, growing environment and type of utilization. Still research is on-going to isolate the bioactive compounds [3].

Decalepis hamiltonii Wight \& Arn is a monotypic, glabrous, climbing shrub belonging to the family Periplocaceae. This is an endemic and endangered medicinal plant and grows largely in moist as well as dry deciduous forests, scrub jungles of southern parts of Deccan Peninsula and the Western Ghats of India [4]. The roots are aromatic and highly valued for medicinal properties. The roots are pale brown in colour and grow up to $150 \mathrm{~cm}$ in length and $3.5 \mathrm{~cm}$ width. During summer, the plant appears deciduous, whereas the fruit follicles and tubers persist. [5].The seeds are elliptic and flattened, with a coma of white to yellowish hairs up to $2.9 \mathrm{~cm}$ long at the micropylar end. Coma hair color varies significantly within species and is not taxonomically informative. The seeds are slightly keeled at the point of attachment to the placenta. The color ranges from dark red-maroon to dull black and varies within the species [6].

Diabetes mellitus(DM) is an endocrine disorder characterized by hyperglycemia is associated with disturbances of carbohydrate, fat and protein metabolism resulting from defects in insulin secretion, insulin action, or both.[7] Alpha( $\alpha$ )-amylase is a prominent enzyme found in the pancreatic juice and saliva which breaks down large insoluble starch molecules in to absorbable molecules. On the other hand, mammalian $\alpha$-glucosidase in the mucosal brush border of the small intestine catalyzes the end step of digestion of starch and disaccharides that are abundant in human diet. An effective means of lowering the levels of postprandial hyperglycemia have been offered by $\alpha$-amylase and $\alpha$-glucosidase inhibitors. Several inhibitors of $\alpha$-amylase and $\alpha$ glucosidase has been isolated from medicinal plants to serve as an alternative drug with increased potency and lesser adverse effects than existing synthetic drugs. Alpha- amylase and Alpha-glucosidase inhibitors are drug-design targets in the development of compounds for the treatment of diabetes, obesity and hyperlipaemia. [8] The present study was carried out to investigate the inhibitory potentials of the methanolic extract of Decalepis hamiltonii on alpha amylase and alpha glucosidase, the key enzymes responsible for carbohydrate hydrolysis.

\section{Materials and Methods}

Plant Materials

The Decalepis hamiltonii Wight and Arn seed was collected from Baskaran Ayurvedic Shop of Kumbakonam, Tamil Nadu state, India. It was identified and authenticated by Prof. Dr.L.Mullainathan, Department of Botany, Annamalai University, Chidambaram, India.

\section{Chemicals and Reagents}

p-nitro-phenyl- $\alpha$-D-glucopyranoside (p-NPG), sodium carbonate $\left(\mathrm{Na}_{2} \mathrm{CO}_{3}\right)$, sodiumdihydrogen phosphate, di-sodium hydrogen phosphate were purchased from Hi-Media, India. Mumbai Alphaamylase from Aspergillus oryzae, $\alpha$-glucosidase from Saccharomyces cerevisiae and paranitrophenyl-glucopyranoside were products of Noor Enzymes Pvt Ltd, West Bengal, India while starch soluble (extra pure) was obtained from Sisco Research Laboratories Pvt. Ltd. Mumbai, India. Other chemicals and reagents were of analytical grade and water used was glass distilled.

\section{Extraction and Isolation}

About $2.0 \mathrm{Kg}$ of dried, coarsely powdered plant material was extracted with methanol using Soxhlet apparatus. Evaporation of the solvent yielded a semisolid mass, which was further dried and used for isolation of phytochemicals. Gradient fractionation of acetone soluble part was performed by eluting the column with benzene: ethylacetate: methanol ( $4: 4: 2)$ followed by methanol over silica gel (60-120 mesh) and elution with chloroform afforded a coloured band, which yielded a pure crystalline material. The isolated active compound was subjected to TLC and eluted with hexane, chloroform and methanol (20:60:20). A single spot was observed by spraying with ferric chloride $\left(R_{f}=0.72\right)$.

\section{Structural Analysis}

IR (Kbr): 2920-3095 (-OH broad), 1622(C=O), 1526, 1460, 1365, $1282(\mathrm{C}-\mathrm{O}-\mathrm{C}), 1140(\mathrm{C}-\mathrm{O}), 1072,1036,968$ and $860 \mathrm{~cm}^{-1}$

${ }^{1}$ H-NMR (DMSO-d6, 300 MHZ): d 9.22(s), 6.70 (1H, H6, 8, s), 6.58 $\left(1 \mathrm{H}, \mathrm{H} 22^{\prime}, \mathrm{H}^{\prime}, \mathrm{s}\right), 6.62 \quad\left(1 \mathrm{H}, \mathrm{H} 6{ }^{\prime}, \mathrm{s}\right), 5.86(\mathrm{~s}), 5.68(1 \mathrm{H}, \mathrm{H} 5, \mathrm{H} 7, \mathrm{~s}), 4.84$ $(1 \mathrm{H}, \mathrm{H} 3$ ', H4', s), $4.47(1 \mathrm{H}, \mathrm{H} 3, \mathrm{~s}), 3.38(1 \mathrm{H}, \mathrm{H} 3, \mathrm{~s}), 3.38(\mathrm{~s}), 2.65(2 \mathrm{H}$, $\mathrm{H} 4, \mathrm{~d})$ and $2.36(\mathrm{~s})$

${ }^{13}$ C- NMR (DMSO-d6, 100 MHZ): 1526.40 (C7), 156.12 (C5), 154.30 (C3'), 144.72 (C4'), 131.54 (C8), 119.39 (C6), 115.53 (C6'), 116.46 (C9), $99.61(\mathrm{C} 10), 96.06\left(\mathrm{C}^{\prime}\right), 93.20\left(\mathrm{C}^{\prime}\right), 81.94(\mathrm{C} 3), 65.26(\mathrm{C} 2)$ and $28.80(\mathrm{C} 4)$

The isolated Bioactive compound was identified as D-catechin or (+)catechin $\left(\mathrm{C}_{15} \mathrm{H}_{14} \mathrm{O}_{6}\right)$ through IR, 1H-NMR and ${ }^{13} \mathrm{C}-\mathrm{NMR}$ spectroscopy. Finally recorded spectroscopic data of isolated compound was compared with previous Literatures to assign their identity[9]. 


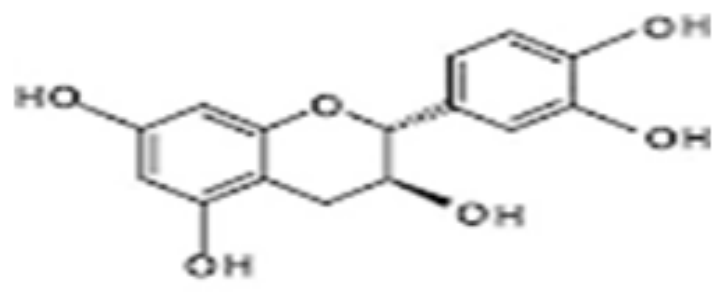

Figure-1 Chemical structure of D-catechin

Evaluation of In-vitro Alpha - Amylase and Alpha - Glucosidase Inhibition Activity

\section{Alpha-Amylase Inhibitory activity}

Alpha-amylase inhibitory activity of $\mathrm{MeOH}$ extract and D-catechin were carried out according to the standard method with minor modification [10]. In a 96-well plate, reaction mixture containing 50 $\mu \mathrm{L}$ phosphate buffer $(100 \mathrm{mM}, \mathrm{pH}=6.8), 10 \mu \mathrm{L} \alpha$-amylase $(2 \mu / \mathrm{mL})$, and $20 \mu \mathrm{L}$ of varying concentrations of $\mathrm{MeOH}$ extract and Catechin $(0.1,0.2,0.3,0.4$, and $0.5 \mathrm{mg} / \mathrm{mL})$ were pre incubated at $300 \mathrm{~K}$ for 20 $\mathrm{min}$. Then, the $20 \mu \mathrm{L}$ of $1 \%$ soluble starch $(100 \mathrm{mM}$ phosphate buffer $\mathrm{pH} 6.8$ ) was added as a substrate and incubated further at $310 \mathrm{~K}$ for 30 min; $100 \mu \mathrm{L}$ of the DNS colour reagent was then added and boiled for $10 \mathrm{~min}$. The absorbance of the resulting mixture was measured at 540 $\mathrm{nm}$ using Multiplate Reader (Multiska thermo scientific, version $1.00 .40)$. Acarbose at various concentrations $(0.1-0.5 \mathrm{mg} / \mathrm{mL})$ was used as a standard. Without test substance was set up in parallel as control and each experiment was performed in triplicates. The results were expressed as percentage inhibition, which was calculated using the formula,

$$
\% \text { Inhibition }=\left[\frac{A c-A s}{A c}\right] \times 100
$$

Where, As is the absorbance in the presence of test substance and Ac is the absorbance of control.

\section{Alpha-glucosidase inhibitory activity}

Alpha-glucosidase inhibitory activity of $\mathrm{MeOH}$ extract and D catechin were carried out according to the standard method with minor modification [11]. In a 96-well plate, reaction mixture containing 50 $\mu \mathrm{L}$ phosphate buffer $(100 \mathrm{mM}, \mathrm{pH}=6.8), 10 \mu \mathrm{L} \quad \alpha$-glucosidase $(1 \mathrm{U} / \mathrm{mL})$, and $20 \mu \mathrm{L}$ of varying concentrations of $\mathrm{MeOH}$ extract and Catechin $(0.1,0.2,0.3,0.4$, and $0.5 \mathrm{mg} / \mathrm{mL})$ were preincubated at 310 $\mathrm{K}$ for $15 \mathrm{~min}$. Then, $20 \mu \mathrm{L} \mathrm{p}-\mathrm{NPG}(5 \mathrm{mM})$ was added as a substrate and incubated further at $310 \mathrm{~K}$ for $20 \mathrm{~min}$. The reaction was stopped by adding $50 \mu \mathrm{L} \mathrm{Na}_{2} \mathrm{CO}_{3}(0.1 \mathrm{M})$. The absorbance of the released $p$-nitrophenol was measured at $405 \mathrm{~nm}$ using Multiplate Reader. Acarbose at various concentrations $(0.1-0.5 \mathrm{mg} / \mathrm{mL})$ was included as a standard. Without test substance was set up in parallel as a control and each experiment was performed in triplicates. The results were expressed as percentage inhibition, which was calculated using the formula,

$$
\% \text { Inhibition }=\left[\frac{A c-A s}{A c}\right] \times 100
$$

Where, As is the absorbance in the presence of test substance and Ac is the absorbance of control.

Effect of $\alpha$-Amylase and $\alpha$-Glucosidase Inhibitory Effects of Methanolic Extract, D -catechin and Acarbose

\begin{tabular}{|c|c|c|}
\hline Substance & $\begin{array}{c}\text { Ic50 values of } \boldsymbol{\alpha}- \\
\text { amylase }(\mathbf{m g} / \mathbf{m L})\end{array}$ & $\begin{array}{c}\text { Ic50 values of } \boldsymbol{\alpha}- \\
\text { glucosidase }(\mathbf{m g} / \mathbf{m L})\end{array}$ \\
\hline Acarbose & $<0.1$ & 0.092 \\
\hline MeOH extract & 0.922 & 0.782 \\
\hline D-catechin & 0.556 & 0.512 \\
\hline
\end{tabular}

\section{RESULT AND DISCUSSION}

\section{Structure of D-catechin}

In IR spectra of D-catechin, a very intensively broad peak at $3095 \mathrm{~cm}^{-1}$ and moderately intense peak at $1365 \mathrm{~cm}^{-1}$ were observed for the $\mathrm{O}-\mathrm{H}$ bond vibrations which can be attributed to $-\mathrm{OH}$ groups. The aromatic
$\mathrm{C}=\mathrm{C}$ vibrations was shown around $1526 \mathrm{~cm}^{-1}$ as weakly intense peak. The stretching and bending vibrations of methylene part were observed as an intense peak at $2920 \mathrm{~cm}^{-1}$ and a medium intensity peak at $1368 \mathrm{~cm}^{-1}$. The very weak peak at $730 \mathrm{~cm}^{-1}$ was attributed to the methylene rocking. The corresponding -C-C- vibration was observed as weak intense peak at $1039 \mathrm{~cm}^{-1}$. A peak at $1622 \mathrm{~cm}^{-1}$ observed may be due to asymmetric C-O-C stretch for lactone and aromatic benzonoid ring. The peaks in the region 1521-1365 $\mathrm{cm}^{-1}$ may be due aromatic$\mathrm{C}=\mathrm{C}$ - stretching. Other stretchings were comparable with IR spectra of authentic D-catechin. The ${ }^{1} \mathrm{H}-\mathrm{NMR}$ spectra of D-catechin showed that the signal at $\delta 9.22$ due to aromatic phenolic groups. The signals at $\delta 6.62,6.58,6.60,5.86$ and 5.68 are due to five different aromatic protons. D-Catechin molecule contains 1 secondary carbon, 7 tertiary carbons and 7 quaternary carbons. In the ${ }^{13} \mathrm{C}$-NMR spectra, signals appeared at $\delta 27.80,66.26,80.94,93.80,95.05,99.01114 .46,115.03$, 118.39 due to C-4, C-2, C-3, C-2, C-5, C-10, C-9, C-3', C-6 carbons respectively and others aromatic carbons showed peaks at $\delta 99.61$, $131.54,144.72,154.30,156.12$ and 156.12 (C-5 to C-10). These data were also in good agreement with the authentic D-catechin. The data correlates the structure of the isolated compound to D-catechin.

\section{Alpha-Amylase and Alpha -Glucosidase Inhibitory Activity} $\alpha$-amylase begins the process of carbohydrate digestion by hydrolysis of 1, 4-glycosidic linkages of polysaccharides (starch, glycogen) to disaccharides and $\alpha$-glucosidase catalyzes the disaccharides to monosaccharides, which leads to postprandial hyperglycemia. .Acarbose was used as a standard reference drug, which showed $\alpha$-amylase inhibitory activity with an $\mathrm{IC}_{50}$ value of $<0.1 \mathrm{mg} / \mathrm{mL}$ and $\alpha$ glucosidase inhibitory activity with an $\mathrm{IC}_{50}$ value of $0.092 \mathrm{mg} / \mathrm{mL}$. Among the extracts, methanolic extract has shown better enzyme activity with an $\mathrm{IC}_{50}$ value 0.922 and 0.782 ( $\alpha$-amylase and $\alpha$ glucosidase) [Table-1], which was comparable with that of standard acarbose. The expected bioactive components could be flavonols or phenolic acids as literature shows a clear link between polyphenols and antidiabetic activity of herbal extracts [12]. Due to above reasons, methanolic extract showed comparable results with that of acarbose. With the help of result in correlation with previous reports, it can be hypothesized that the significant enzyme inhibitory activity of methanolic extract may interfere or delay the absorption of dietary carbohydrates as well as disaccharides in the small intestine, leading to the suppression of meal-induced increase of plasma glucose. Methanolic extract showed the greater \% inhibition of the alpha glucosidase enzyme compared to D-catechin. The plant extracts produced a slightly weak alpha glucosidase enzyme inhibition when compared with alpha amylase. The present study indicated that Decalepis hamiltonii could be useful in management of postprandial hyperglycemia. Since the methanolic extract showed significant inhibition activity, further the isolation of compound, which is responsible for inhibiting activity and its characterization have to be carried out to use it as an antidiabetic agent.

\section{CONCLUSION}

The isolated Bioactive compound was identified as D-catechin $\left(\mathrm{C}_{15} \mathrm{H}_{14} \mathrm{O}_{6}\right)$ through IR, ${ }^{1} \mathrm{H}-\mathrm{NMR}$ and ${ }^{13} \mathrm{C}-\mathrm{NMR}$ spectroscopy. Finally recorded spectroscopic data of isolated compound was compared with previous Literatures to assign their identity. Diabetes mellitus is one of the most common endocrine diseases characterized by hyperglycemia due to absolute or relative deficiency of insulin. One antidiabetic therapeutic approach is to reduce gastrointestinal glucose production and absorption through the inhibition of alpha amylase enzyme plays a major role in preventing rise in postprandial glucose level in diabetics. Several $\alpha$ - amylase inhibitors including acarbose, voglibose and miglitol are clinically used for treatment but their prices are high and clinical side effects occur [13]. Hence screening of $\alpha$-glucosidase inhibitors from plants and synthetic sources is increasing and inhibitors of these enzymes have been recently developed from natural sources.

\section{Conflicts of Interest}

There are no conflicts of interest

\section{Acknowledgement}

Authors are thankful Bio Focus research Lab, Thanjavur for providing the necessary facilities to carry out the work.

\section{REFERENCES}

1. Wadood A, Ghufran M, Jamal SB, Naeem M, Khan A, et al(2013). "Phytochemical Analysis of Medicinal Plants Occurring in Local Area of Mardan", Biochemistry and 
Analytical Biochemistry.2(4);138-144

2. Chandrasekhara Reddy K, and Sri Rama Murthy K(2013), A review on Decalepis hamiltonii Wight \& Arn "Journal of Medicinal Plants Research", 7(4);3014-3029.

3. Shyam T, and Ganapaty S(2013), "Evaluation of Antidiabetic Activity of Methanolic Extracts from the Aerial Parts of Barleria montanain Streptozotocin Induced DiabeticRats",Journalof Pharmacognosy and Phytochemistry, 2(1);192-197.

4. Rayar A and Manivannan R(2016), "Antidiabetic Effect of Ethanolic Seed Extract of Decalepis Hamiltonii Wight and Arn on Oxidative Stress and Enzymic Activities in Alloxan Induced Diabetic Rats”., International Journal of Pharmaceutical Sciences and Research", 7(1);292-299. .doi: 10.13040/IJPSR.0975-8232.7(1).292-99.

5. Naveen S and Khanum F (2010), "Antidiabetic, antiatheroscrerotic and hepatoprotective properties of Decalepis hamiltonii in streptozotocin induced diabetic rats". Journal of Agricultural and Food Chemistry', 3(1);2010),1231-1248.

6. Devi M and Latha $\mathrm{P}(2012)$, "Antibacterial and phytochemical studies of various extracts of roots of Decalepis hamiltonii Wight and Arn".,. International Journal of Pharmacy of roots of Decalepis hamiltonil Wight and Arn".,. International Journal of Pharmacy and Pharmaceutical Sciences", 4(1);738-740.

7. Numao S(2016), "A single bout of exercise and postprandial hyperglycemia caused by high-fat diet," The Journal of Physical Fitness and Sports Medicine, 5(2); 181-185.

8. Afifi AF, Kamel EM, Khalil AA, Foaad MA, Fawziand EM, and Houseny M(2008), "Purification and characterization of a-amylase from penicillium olsonii under the effect of some antioxidant vitamins.," Global Journal of Biotechnology and Biochemistry, 3(1); 14-12.

9. Rayar A and Manivannan R 2016)," Antioxidant and Anticancer Activities of (+)Catechin Isolsted From Annona Reticulata Linn"International Journal of Recent Scientific Research,7(1);9451-9456.

10. Ademiluy AO and Oboh G(2013), "Soybean phenolic-rich extracts inhibit key-enzymes linked to type 2 diabetes ( $\alpha$-amylase and $\alpha$-glucosidase) and hypertension (angiotensin I converting enzyme) in-vitro", Experimental and Taxicological Pathology, 65(1);305-309.

11. Sales PM, Souza LA, Simeoni D and Silveira(2012), " $\alpha$-amylase inhibitors, A review of raw material and isolated compounds from plant source"., Journal of Pharmacy and Pharmacutical Science, 15(1);141-183.

12. Min SW and Han S(2014), "Polyopes lancifolia Extract, a Potent $\alpha$-Glucosidase Inhibitor, Alleviates Postprandial Hyperglycemia in Diabetic Mice"., Preventive Nutrition and Food Science, 19(1);5-9.

13. Rayar A and Manivannan R2016), "In-Vitro Alpha-Amylase and Alpha-Glucosidase Inhibition Activity of Umbelliferone And Beta-Ionone Isolated From Coriandrum Sativum Linn". World Journal of Pharmacy and Pharmaceutical Sciences, 5(1), 1280 1289. 